\title{
Genetic Variability, Traits Association and Path Coefficient Analysis in Advanced Lines of Groundnut (Arachis hypogaea L.)
}

\author{
Muhammad Jahanzaib ${ }^{1 *}$, Nazakat Nawaz ${ }^{1}$, Muhammad Arshad ${ }^{1}$, Haris Khurshid ${ }^{1}$, Muzamil Hussain ${ }^{2}$ \\ and Shahid Ali Khan ${ }^{1}$
}

${ }^{1}$ Oilseeds Research Program, Crop Sciences Institute, National Agricultural Research Centre, Islamabad, Pakistan; ${ }^{2}$ Agricultural Engineering Institute, National Agricultural Research Centre, Islamabad, Pakistan.

\begin{abstract}
Groundnut (Arachis hypogaea L.) is an important grain legume crop. However, there is still great need to develop superior varieties and lift its production. Germplasm characterization plays a vital role in improved cultivars' development. The current study was conducted to estimate genetic variability, traits association, and path coefficient analysis in eleven groundnut advanced breeding lines together with check vis BARD-479, using randomized complete block design with three replications at National Agricultural Research Centre, Islamabad, Pakistan. Through One-Way Analysis of variance significant discrepancies were found among the genotypes for most of the traits. In this study 100 kernels weight was found in significant positive correlation $(0.821 * *)$ with twenty pods length, while in significant negative correlation $(-0.850 * *)$ with plant width. Similarly, the trait of dry pods yield was in significant positive correlation $\left(1.216^{* *}\right)$ with plant height, while was significant negatively correlated $\left(-.850^{* *}\right)$ with number of branches. A strong positive direct effect was observed between twenty pods length (5.548), shelling percentage (4.630), 100-kernels weight (3.738), and leaflet length (2.950) with dry pods yield, indicating the importance of traits linkage in groundnut genotypes improvement. A weak direct effect was found among morphological traits i.e., number of branches (1.419), plant height (.311), and plant width (1.058). A strong indirect effect was witnessed by Leaflet width (-2.225) with dry pods yield. Furthermore, genotypes PG-1221, PG-1259, PG-1254, and PG-1266 were found with promising yield potential of $3637 \mathrm{Kg} / \mathrm{ha}, 3430 \mathrm{Kg} / \mathrm{ha}, 3286 \mathrm{Kg} / \mathrm{ha}$, and $3176 \mathrm{Kg} / \mathrm{ha}$, respectively, hence recommended for further evaluation through future breeding program.

Received | August 25, 2020; Accepted | November 30, 2020; Published | March 30, 2021

*Correspondence | Muhammad Jahanzaib, Oilseeds Research Program, Crop Sciences Institute, National Agricultural Research Centre, Islamabad, Pakistan; Email: m.jahanzaib548@gmail.com

Citation | Jahanzaib, M., Nawaz, N., Arshad, M., Khurshid, H., Hussain, M. and Khan, S.A., 2020. Genetic; variability, traits association and path coefficient analysis in advanced lines of groundnut (Arachis hypogaea L.). Journal of Innovative Sciences, 7(1): 88-97.

DOI | http://dx.doi.org/10.17582/journal.jis/2021/7.1.88.97

Keywords | Groundnut, Genetic variability, Yield, Character association, Path coefficient analysis
\end{abstract}

\section{Introduction}

$\mathrm{G}$ roundnut (Arachis bypogaea L.) is an allotetraploid $\mathbf{J}(2 n=4 x=40)$, most probably originated in the region of eastern foothills of Andes, Southern Bolivia, and Northern Argentina (Hampannavar and Khan, 2019). It is widely grown as an oilseed and food crop in more than 144 countries worldwide, where commercial production mostly confined between $40^{\circ} \mathrm{S}$ and $40^{\circ} \mathrm{N}$ latitudes. Groundnut is presumed to be domesticated in South America about 6 thousand years ago followed by widely distribution in postColumbian times. As a rich source of seed oil ( 46$58 \%)$ and protein $(\sim 22-32 \%)$, it has great potential to cope with the problem of malnutrition and to ensure food security (Zhuang et al., 2019). Groundnut is also a good source of minerals and vitamins including vitamin E, niacin, phosphorus, falcin, calcium, 
riboflavin, magnesium, zinc, iron, thiamine, and potassium (Jibrin et al., 2016). Besides, the haulm is a good source of animal feed as well as industrial raw material. More importantly, groundnut contributes in soil fertility by fixation of atmospheric nitrogen (Nigam, 2014). Groundnut is widely known as poor man's almonds due to its high nutritional contents as well as fat and protein level, making up $80 \%$ of seeds contents. Furthermore, groundnut is also a vibrant ingredient in numerous delicious commercial products (Pandey et al., 2012; Pandey and Varshney, 2018). Besides, groundnut being a legume crop is an important candidate for crop rotation resulting soil enrichment and fertility via atmospheric nitrogen fixation and breaking pest and disease cycles (Pandey et al., 2020).

Growing demand for food security has spiked the need of genetic improvement of crop germplasm. Genetic variability being a best option for crop cultivar improvement has intensively used in the past (Jaganathan et al., 2020). Unfortunately, the process of new cultivar development in groundnut has been remained a bottleneck due to its comparatively low level of variability among the available germplasm and its complex genome size. Genetic discrepancies among the germplasm of any crop are the basic requirement for crop improvement. Worldwide groundnut germplasm collections are preserved including India with 15,445 accessions, followed by USA with 9310 accessions, and China with 7837 accessions (Pandey et al., 2012). The Arachis genera can be alienated into nine sections comprising of 81 species from two ploidy groups (diploid and tetraploid) with enormous diversity of genomes including $A$, B, AB, D, F, K, EX, T, PR, H, C, T, E, R1 and R2 (Stalker, 2017). Effectiveness of superior genotype selection is primarily reliant on the availability of large genetic variability in the germplasm for the trait of interest and the degree of its heritability (Hugar and Savithramma, 2015; Padmaja et al., 2015). The selection is further valued by the direction and extent of association between the traits of interest (Shrey et al., 2015). The association analysis creates statistics about the relationship among the traits of interest and thus possibility of indirect selection, when required. Similarly, path coefficient analysis provides knowledge about the direct and indirect effects of specific trait on other traits and finally on the trait of yield. In case of peanut selection for productive lines based on phenotypic traits is not so effective due to hypogeal nature of its fruit. Direct or indirect selection option for yield-related traits is highly worthwhile, most suitable in case of segregating populations. In this regards correlation analysis is useful since information about the nature and magnitude of interrelationships among various traits is not only important in defining the selection potential of an isolated trait but also identifies the effects on a particular trait based on the selection for another trait (Cruz and Regazzi, 1997). The significance of the traits correlations in genetic improvement defends on how the variation in one trait has the ability to affect others during a selection process (Santos et al., 2000). Though, selection strategies which are based on the correlations between traits can only encourage errors, since their association with each other might be linked to a third trait or even to a group of traits in most cases (Cruz and Regazzi, 1997). The correlation coefficient between any two traits cannot give a comprehensive picture of a complex trait like yield, which is jointly determined by several traits in the form of direct and indirect effects. Therefore, the level of applicability of correlations can more clearly be understood using the path analysis. Path analysis allows the division of correlation into direct and indirect effects resulting as a valuable tool in various breeding programs in a wide array of crops (Gomes et al., 2007; Gomes and de Almeida Lopes, 2005; Oliveira et al., 2007).

Keeping in view the importance of the above mentioned provisions in new cultivar development this study was carried out with the objectives to estimate the genetic variability, traits association, and path coefficient analysis for yield and yield-related traits in groundnut germplasm comprising eleven advanced lines. This study will help in harnessing the existing genetic variability among evaluated advanced lines and selection of superior lines in future breeding programs.

\section{Materials and Methods}

\subsection{Study area and experimental material}

The current study was conducted at the Oilseed Research Program, National Agricultural Research Centre (NARC), Islamabad, Pakistan $\left(33.6701^{\circ} \mathrm{N}\right.$, $73.1261^{\circ} \mathrm{E}$ latitude with 540 meters altitude). The experimental design used was randomized complete block design (RCBD) with three replications. Groundnut germplasm evaluated in this study comprised of eleven advanced breeding lines along 
with check cultivar, BARD-479 (Table 1).

Table 1: Genotypes used in the study.

\begin{tabular}{lll}
\hline S. No. & Code & Identity \\
\hline 1 & 479 & BARD-479 \\
2 & PG-1221 & ICG-6590 \\
3 & PG-1254 & BARD-479 x PG-1058 \\
4 & PG-1255 & BARD-479 x PG-1058 \\
5 & PG-1256 & BARD-92 x PG-1053 \\
6 & PG-1258 & BARD-92 x PG-1053 \\
7 & PG-1259 & BARD-92 x PG-1053 \\
8 & PG-1261 & PG-1050 x PG-1074 \\
9 & PG-1262 & PG-1050 x PG-1074 \\
10 & PG-1265 & PG-1058 x PG-668 \\
11 & PG-1266 & PG-5 x PG-1058 \\
12 & PG-1267 & PG-5 x PG-1058 \\
\hline
\end{tabular}

\subsection{Crop busbandry}

Recommended cultural practices were applied during the crop growing season. For seedbed preparation two ploughings were made, followed by planking. The genotypes were planted on $15^{\text {th }}$ of April, 2019, on sandy loam soils in three rows of 4 meters length for each entry with a row-to-row distance of $50 \mathrm{~cm}$ and plant to plant $15 \mathrm{~cm}$. The seed rate at sowing was kept $75 \mathrm{~kg} / \mathrm{ha}$. Nitrogen, Phosphorus, and Potassium (NPK) fertilizer was applied @ rate of 20-80-50 kg/ ha and other cultural operations such as weeding, hoeing, and use of insecticides were applied.

\subsection{Data recording and statistical analysis}

Five plants from each advanced line as well as check cultivar were randomly selected and data were recorded. Data were recorded and analyzed on nine traits including number of branches, plant height, plant width, twenty pods length, shelling percentage, 100-kernel weight, leaflet length, leaflet width, and dry pods yield. For all the studied genotypes and characterized traits One-Way Analysis of Variance (ANOVA) was calculated using Statistix 8.1 (2003). The genotypic coefficient of variance (GCV) and phenotypic coefficient of variance (PCV) were calculated according to Burton (1952), the genotypic and phenotypic correlations were determined according to Al-Jibouri et al. (1958), and the path coefficient analysis was calculated according to Dewey and $\mathrm{Lu}$ (1959). Data were analyzed statistically by using software Statistix 8.1 (2003) and Microsoft Excel (2010).

Journal of Innovative Sciences

June 2021 | Volume 7 | Issue 1 | Page 90

\section{Results and Discussion}

ANOVA revealed significant differences among the genotypes for most of the traits (Table 2). Differences found among the genotypes for the characterized traits showing the presence of genetic variability among these genotypes for the studied traits.

Table 2: Analysis of variance for the characterized traits in the study.

\begin{tabular}{|c|c|c|c|c|}
\hline $\begin{array}{l}\text { S. } \\
\text { No }\end{array}$ & Traits & Means \pm SD & $\mathrm{CV}$ & $\begin{array}{l}\text { Differ- } \\
\text { ences }\end{array}$ \\
\hline 1 & Number of branches & $10.250 \pm 2.260$ & 22.050 & NS \\
\hline 2 & Plant height & $65.820 \pm 10.470$ & 15.910 & $* *$ \\
\hline 3 & Plant width & $107.110 \pm 15.170$ & 14.160 & ** \\
\hline 4 & Twenty pods length & $67.920 \pm 7.480$ & 11.010 & ** \\
\hline 5 & Shelling Percentage & $66.280 \pm 4.190$ & 6.330 & $* *$ \\
\hline 6 & 100-kernel weight & $72.140 \pm 13.180$ & 18.270 & ** \\
\hline 7 & Leaflet length & $5.370 \pm 0.880$ & 16.310 & NS \\
\hline 8 & Leaflet width & $1.980 \pm 0.470$ & 23.810 & ** \\
\hline 9 & Dry pods yield & $1578.280 \pm 323.340$ & 20.490 & NS \\
\hline
\end{tabular}

\subsection{Number of branches per plant}

Most of the agronomic traits contribute positively towards yield in peanut. Number of branches per plant is one of these traits. In this study no significant discrepancies were observed among the genotypes for the trait of number of branches (Table 2; Figure 1 ), which may be the same genetic makeup of the genotypes for the said trait. Highest number of branches was found in advanced line PG-1255 (12.67), followed by PG-1267 (11.67), and check cultivar BARD-479 (11). PG-1266 was found with the lowest number of branches per plant (8). Our finding is in close agreement with that of Chavadhari et al. (2017), who also reported number of branches within the range of 4.07 to 10 .

\subsection{Plant height}

Like other crops the trait of plant height is a key factor in determining peanut architecture traits and has an exceptional effect on resistance to lodging and competence to mechanized harvesting, and more importantly improved yield (Fernandez et al. 2009). Significant variability was observed among the genotypes for the characterized trait of plant height (Table 2; Figure 2). Tallest plants were noted in PG$1265(82.33 \mathrm{~cm})$, followed by PG-1254 $(78.33 \mathrm{~cm})$, and BARD-479 $(73.33 \mathrm{~cm})$, while the lowest plant height 
was found in PG-1258 (47.67 cm). The differences in plant height can be attributed to the genetic variation found among the evaluated genotypes. Our findings are supported by Raza et al. (2017) and Borker and Dharanguttikar (2014), they also reported significant differences for the trait of plant height. Plant height being an important trait, is extensively studied in other studies in peanut (Chavadhari et al., 2017; Yol et al., 2018; Lv et al., 2018).

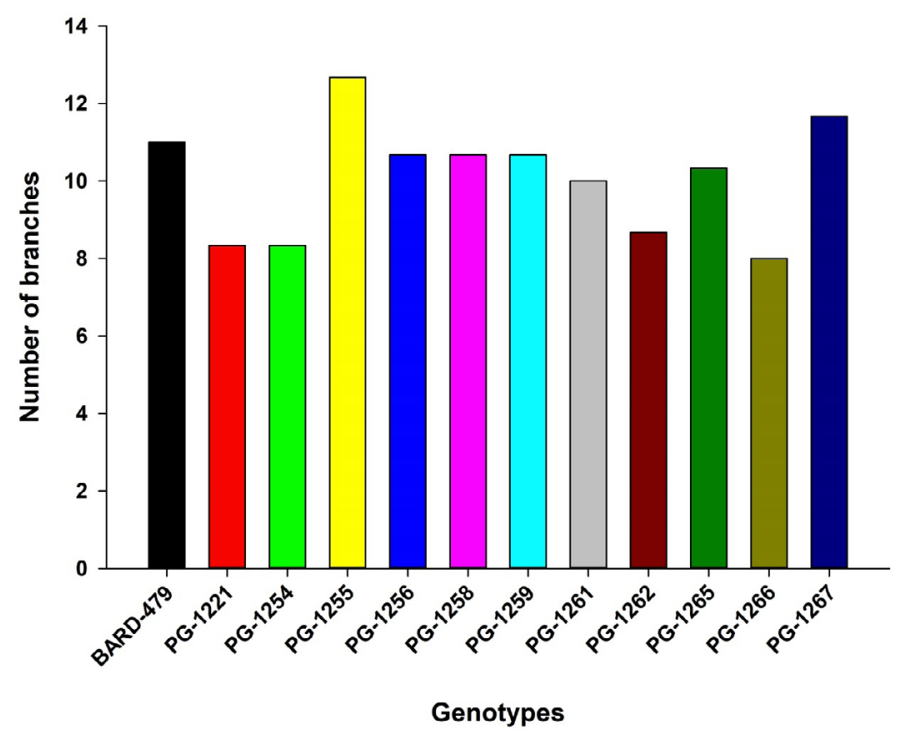

Figure 1: Discrepancies among the genotypes for the trait of number of branches.

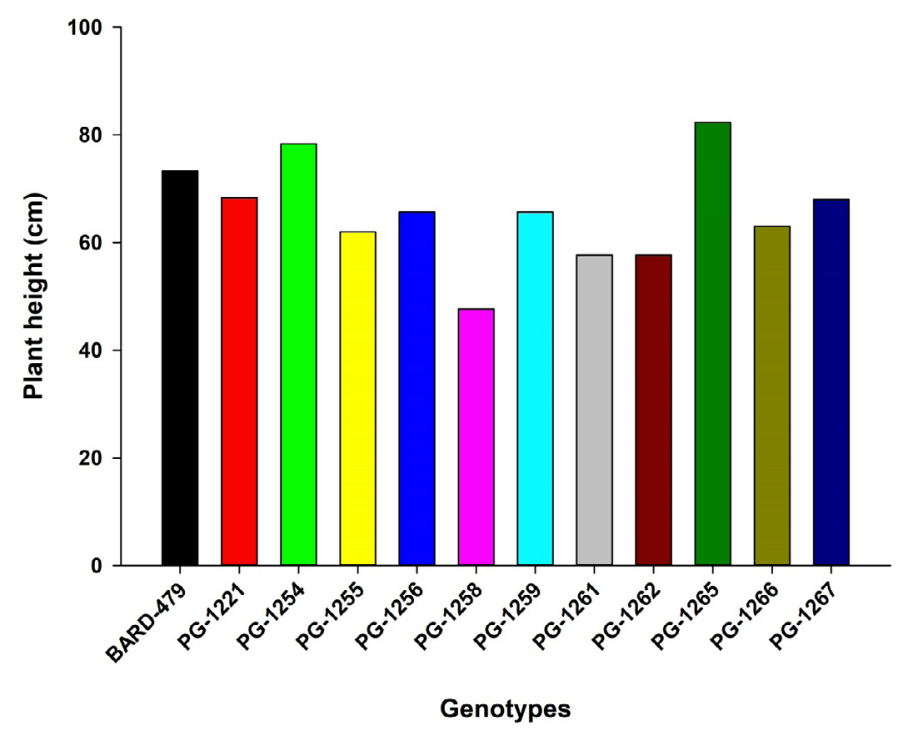

Figure 2: Discrepancies among the genotypes for the trait of plant height.

\subsection{Plant width}

Plant width is another important trait in crops effecting other traits as well as yield potential due to its direct link to the extent of spacing. Overcrowding of crops reduce yields as well as quality because of plants competition for light and soil nutrients. Knowing the plant width can help in maintaining proper plant to plant and row to row distance. In our findings we found significant differences in evaluated genotypes for plant width (Table 2; Figure 3). Widest plant width was noted in PG-1256 (128.67 cm), followed by check cultivar BARD-479 $(121 \mathrm{~cm})$ and PG-1262 $(114.33 \mathrm{~cm})$. The lowest plant width was found in PG-1267 $(83.33 \mathrm{~cm})$. Knowing the plant width, we can maintain proper spacing accordingly and can get optimum yield.

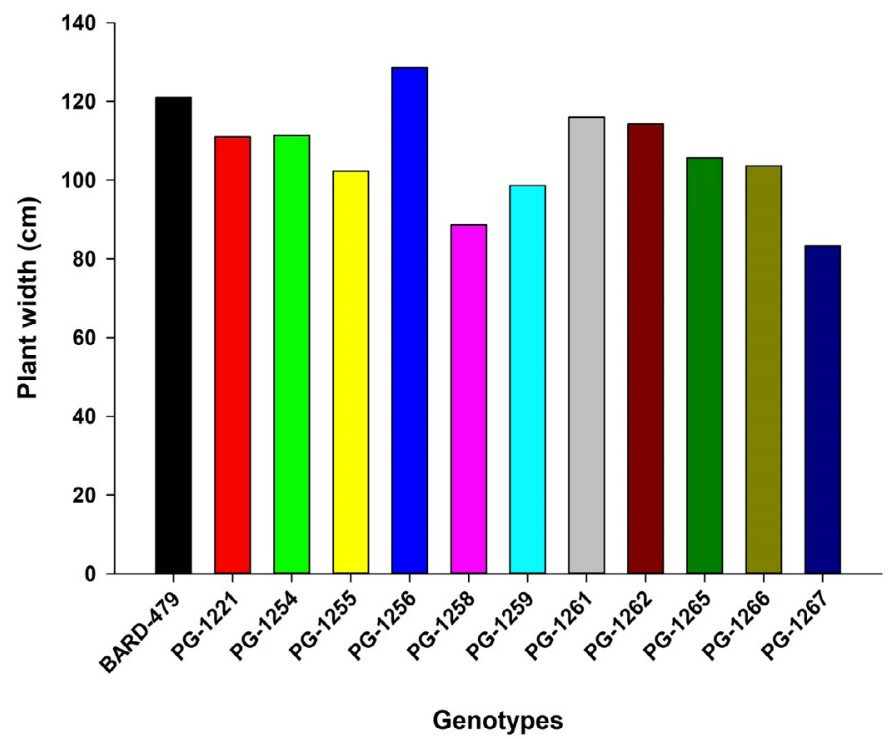

Figure 3: Discrepancies among the genotypes for the trait of plant width.

\subsection{Twenty pods length}

Pod and kernel size are direct contributors in peanut yield. Besides, pod and kernel size plays significant role absorbing nutrients from the soil (Singh et al., 2004). Highly significant differences found among the evaluated genotypes for the trait of twenty pod length (Table 2; Figure 4). Lengthiest twenty pods length found in this study was in advanced line PG$1221(85 \mathrm{~cm})$, followed by PG-1266 $(75.33 \mathrm{~cm})$ and PG-1267 $(74.67 \mathrm{~cm})$. The shortest twenty pods length of $56.67 \mathrm{~cm}$ was observed in PG-1259. Since domestication of groundnut the traits of pod and kernel size have been remained under high selection pressure. Morphological as well as genetic bases have been identified for the improvement of these traits (Chu et al., 2020).

\subsection{Shelling percentage}

Shelling percentage has been considered as an important trait in groundnut cultivar improvement (Lampang et al., 1980). Significant variation found among the genotypes for the trait of shelling 
percentage in current study (Table 2; Figure 5). Highest shelling percentage was noted in PG-1266 (72.17\%), followed by PG-1261 (71.83\%), and PG$1258(69.67 \%)$. The lowest shelling percentage of $57.83 \%$ was found in advanced groundnut line PG126. Our findings are in close agreement with that of Raza et al. (2017), who also reported same trends in shelling percentage.

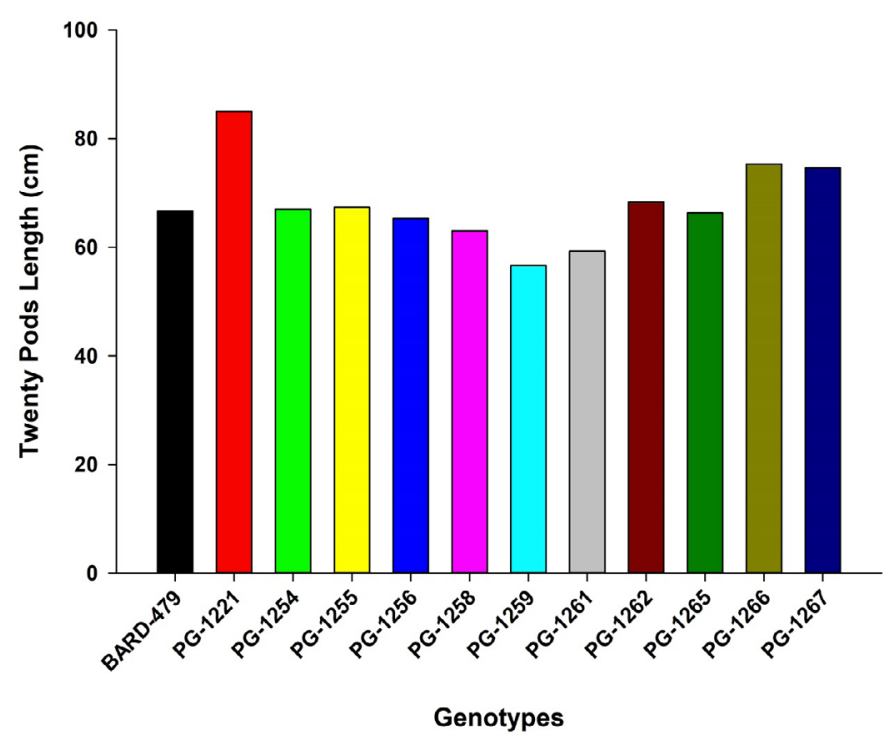

Figure 4: Discrepancies among the genotypes for the trait of twenty pods length.

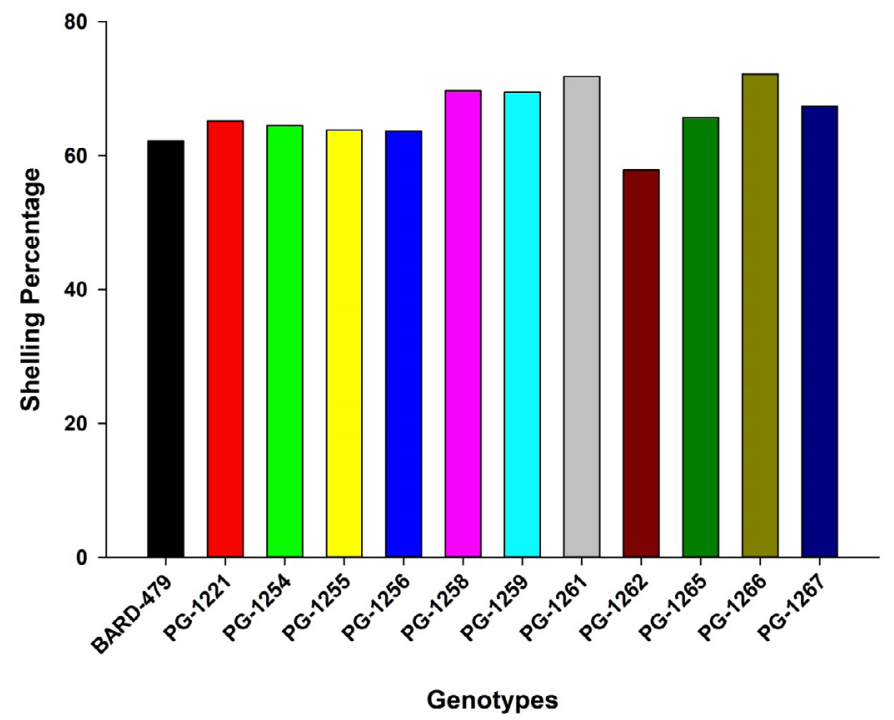

Figure 5: Discrepancies among the genotypes for the trait of shelling percentage.

\subsection{0-kernels weight}

Like other traits 100-kernel weight is an important yield contributing trait in groundnut (Aminifar et al., 2013), affecting directly the crop yield. Significant differences were found in evaluated genotypes for the trait of 100-kernels weight (Table 2; Figure 6), showing extent of variability and the potential of high yielding cultivar development. Genotypes PG-1267 was found with highest 100-kernel weight (95.67 grams), followed by PG-1266 (94.67 grams), and PG1221 (88.67 grams). The lowest 100-kernel weight was noted in PG-1261 (57 grams). Comparable findings for the trait of 100-kernel weight were reported by Raza et al. (2017) and Khan et al. (2009).

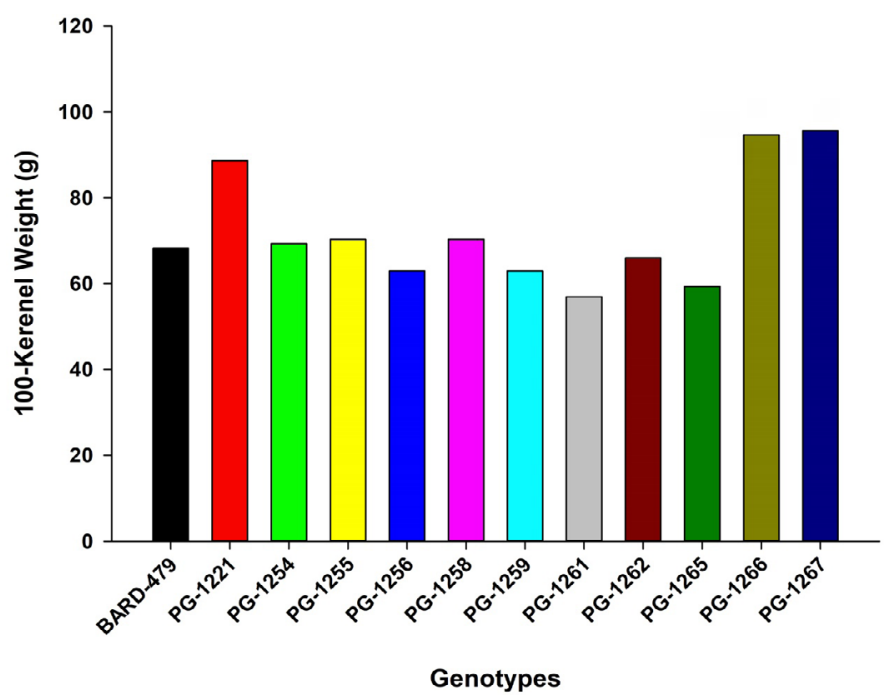

Figure 6: Discrepancies among the genotypes for the trait of 100-kernels weight.

\subsection{Leaflet length}

Leaflet length is among the most important traits. Leaf is the main site of photosynthesis as well as associated with various diseases in groundnut (Coffelt and Porter, 1982). Considerable differences were observed for the trait of leaflet length among the genotypes (Table 2; Figure 7). Largest leaflet length was observed in PG-1258 $(6.17 \mathrm{~cm})$, followed by PG$1255(5.93 \mathrm{~cm})$, and PG-1262 $(5.73 \mathrm{~cm})$. The shortest leaflet length was found in PG-1261 $(4.33 \mathrm{~cm})$.

\subsection{Leaflet width}

In current study significant diversity found for the trait of leaflet width among the studied genotypes (Table 2; Figure 8). Widest leaflet width was seen in advanced line PG-1221 $(2.67 \mathrm{~cm})$, followed by PG$1265(2.37 \mathrm{~cm})$, and PG-1267 $(2.3 \mathrm{~cm})$. The lowest leaflet width $(1.3 \mathrm{~cm})$ was noted in PG-1254.

\subsection{Dry pods yield}

The studied genotypes were genetically diverse for the evaluated traits (Table 2; Figure 9). Among the evaluated advanced lines highest dry pods yield was recorded in PG-1221 (1964.67 grams), followed by BARD-479 (1853.33 grams), and PG-1254 (1775 grams). The lowest (1295.33 grams) dry pods yield was noted in PG-1262. 


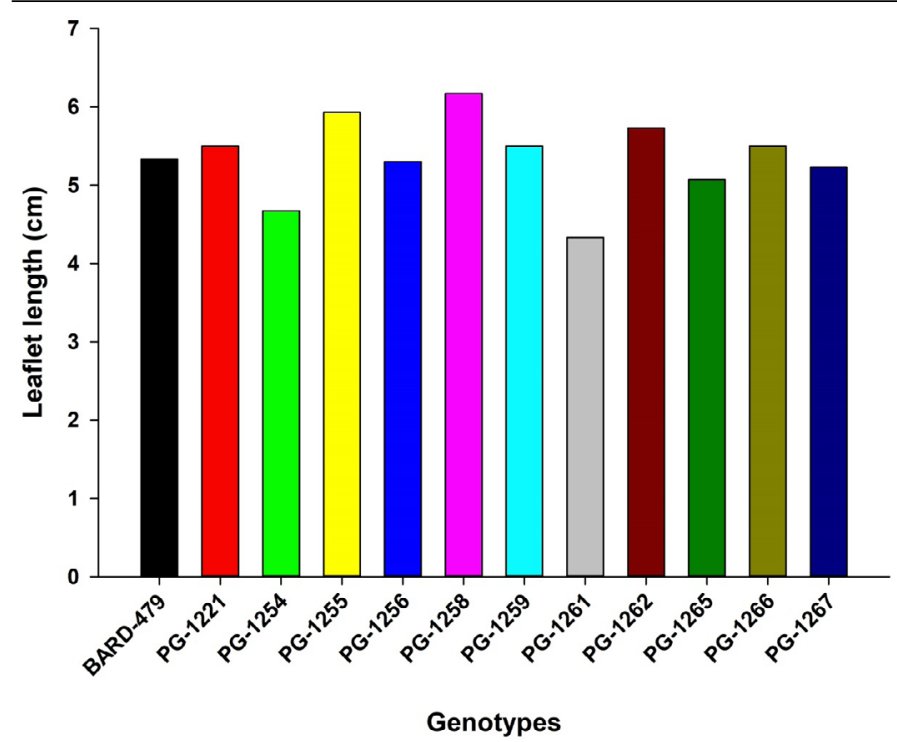

Figure 7: Discrepancies among the genotypes for the trait of leaflet length.

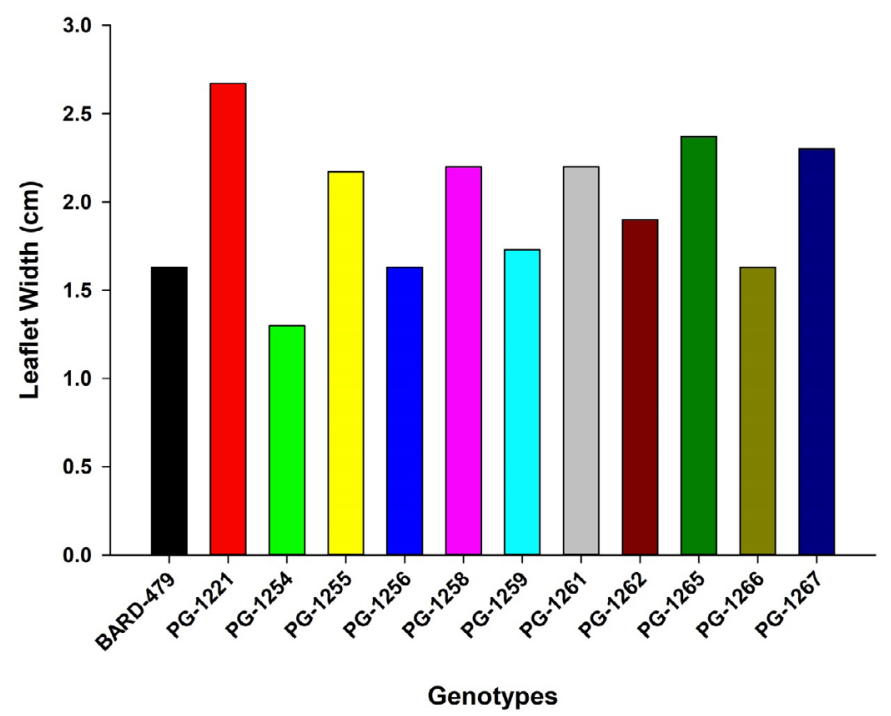

Figure 8: Discrepancies among the genotypes for the trait of leaflet width.

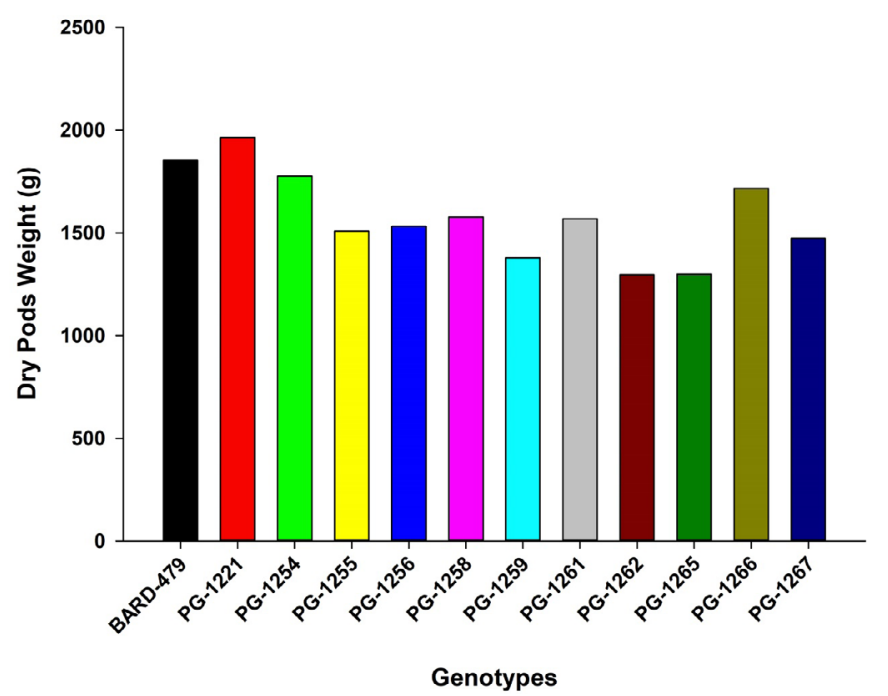

Figure 9: Discrepancies among the genotypes for the trait of dry pods yield.
3.10 Yield $\mathrm{Kg} / \mathrm{ha}$

Like most of other traits yield $\mathrm{kg} / \mathrm{ha}$ was highly significant diversified in the evaluated genotypes (Table 2; Figure 10). Highest yield of $3637 \mathrm{Kg} / \mathrm{ha}$ was obtained from PG-1221, followed by PG-1259 (3430 $\mathrm{Kg} / \mathrm{ha})$, and PG-1254 (3286 Kg/ha). Advanced line PG-1261 was found with lowest yield of $1901 \mathrm{Kg} /$ ha (Table 4).

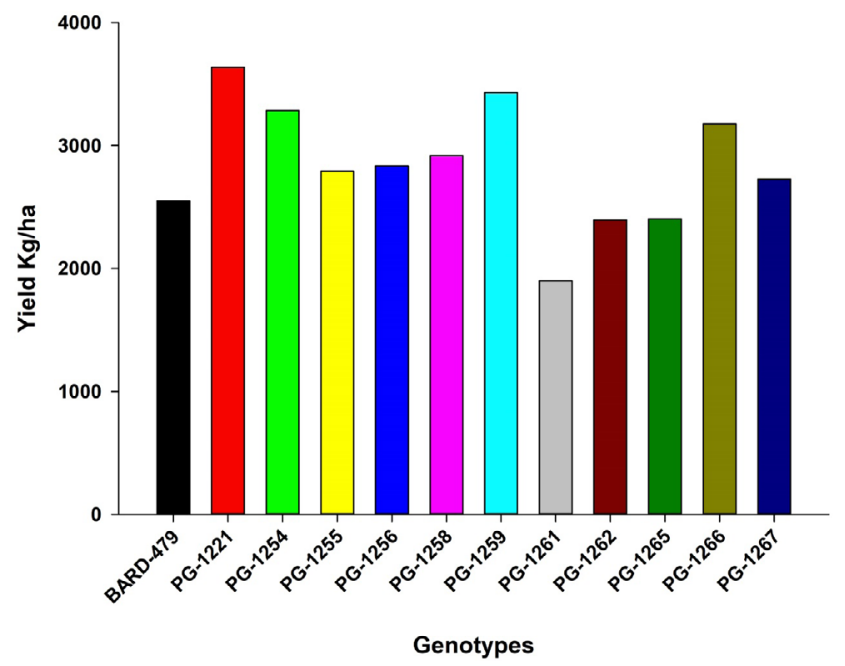

Figure 10: Discrepancies among the genotypes for the trait of dry pods yield.

In this study GCV and PCV were calculated for all pairs of characterized traits (Table 3). Out of the 36 correlation coefficients among 9 traits, 11 correlation coefficients were significant at genotypic level whereas only one correlation coefficient was found significant at phenotypic level (Table 3). Most of GCV values were higher than their corresponding PCV showing the higher level of association between two variables at genotypic level (Table 3). The phenotypic expression of the traits was reduced by environmental influence, directing towards the possibilities of effective phenotypic selection. The trait of 100-kernel weight was highly significant and positively correlated with the traits of twenty pods length $\left(0.821^{* *}\right)$, while highly significant negatively with plant width $\left(-0.850^{* *}\right)$. Dry pods yield was found in highly significant positive correlation with plant height $\left(1.216^{* *}\right)$ and highly negative correlation with number of branches $\left(-0.850^{* *}\right)$. A highly significant and negative correlation was observed among the traits of leaflet width and plant width $\left(-0.984^{* *}\right)$, shelling percentage and plant width $\left(-0.881^{* *}\right)$, plant height and leaflet width $\left(-0.832^{* *}\right)$, Leaflet length and plant width $\left(-0.795^{* *}\right)$, and twenty pods length and number of branches $\left(-0.785^{* *}\right)$. Similarly, the trait of twenty pods length was also found in a 
highly significant positive correlation $\left(1.403^{* *}\right)$ with yield groundnut cultivar development. Significant the trait of plant height (Table 3). In current findings, association between pod yield plant ${ }^{-1}$ and $\mathrm{PH}$ was significantly high association among the traits reflects vital yield attributing traits and therefore importance also recorded by Kushwah et al. (2016). Babariya and Dobariya (2012) also witnessed similar association of should be given to these while breeding for high pod yield per plant with yield contributing characters.

Table 3: Genotypic and phenotypic correlation coefficient among nine studied traits.

\begin{tabular}{llllllllll}
\hline Traits & $\begin{array}{l}\text { Number of } \\
\text { branches }\end{array}$ & $\begin{array}{l}\text { Plant } \\
\text { height }\end{array}$ & $\begin{array}{l}\text { Plant } \\
\text { width }\end{array}$ & $\begin{array}{l}\text { Twenty pods } \\
\text { length }\end{array}$ & $\begin{array}{l}\text { Shelling } \\
\text { Percentage }\end{array}$ & $\begin{array}{l}\text { 100-kernel } \\
\text { weight }\end{array}$ & $\begin{array}{l}\text { Leaflet } \\
\text { length }\end{array}$ & $\begin{array}{l}\text { Leaflet } \\
\text { width }\end{array}$ & $\begin{array}{l}\text { Dry pods } \\
\text { yield }\end{array}$ \\
\hline Number of branches & 1 & -.267 & -.144 & -.285 & -.0129 & -.187 & .146 & .154 & -.198 \\
Plant height & 4.585 & 1 & -.070 & .141 & -.084 & .047 & -.241 & -.171 & .073 \\
Plant width & -1.082 & 7.846 & 1 & -.088 & -.270 & -.338 & -.211 & -.109 & .178 \\
Twenty pods length & $-.785^{* *}$ & $1.403^{* *}$ & -.081 & 1 & -.148 & $.790^{* *}$ & .137 & .289 & .479 \\
Shelling Percentage & -.0746 & -2.620 & $-.881^{* *}$ & -.167 & 1 & .198 & -.185 & .115 & .099 \\
100-kernel weight & -.396 & $-.640^{*}$ & $-.850^{* *}$ & $.821^{* *}$ & .213 & 1 & .223 & .153 & .382 \\
Leaflet length & .551 & -4.680 & $-.795^{* *}$ & .188 & -.229 & .268 & 1 & .090 & -.082 \\
Leaflet width & .430 & $-.832^{* *}$ & $-.984^{* *}$ & .425 & .125 & .216 & .248 & 1 & -.134 \\
Dry pods yield & $-.850^{* *}$ & $1.216^{* *}$ & .459 & .546 & .093 & .4504 & -.142 & -.055 & 1 \\
\hline
\end{tabular}

Significant at $5 \%={ }^{*}$ and significant at $1 \%={ }^{* *}$, Genotypic level= down ward left side of diagonal, Phenotypic level = upward ward right side of diagonal

Table 4: Direct (bold) and indirect effect among studied traits. Where dependent variable is dry pods yield and the last column shows the effects of independent variables on dry pods yield.

\begin{tabular}{llllllllll}
\hline Traits & $\begin{array}{l}\text { Number of } \\
\text { branches }\end{array}$ & $\begin{array}{l}\text { Plant } \\
\text { height }\end{array}$ & $\begin{array}{l}\text { Plant } \\
\text { width }\end{array}$ & $\begin{array}{l}\text { Twenty pods } \\
\text { length }\end{array}$ & $\begin{array}{l}\text { Shelling } \\
\text { Percentage }\end{array}$ & $\begin{array}{l}\text { 100-kernel } \\
\text { weight }\end{array}$ & $\begin{array}{l}\text { Leaflet } \\
\text { length }\end{array}$ & $\begin{array}{l}\text { Leaflet } \\
\text { width }\end{array}$ & $\begin{array}{l}\text { Dry pods } \\
\text { yield }\end{array}$ \\
\hline Number of branches & $(1.419)$ & 1.427 & -1.146 & -4.356 & -.345 & 1.483 & 1.626 & -.958 & -.850 \\
Plant height & 6.505 & $(.311)$ & 8.303 & 7.787 & -12.129 & 2.391 & -13.803 & 1.850 & 1.216 \\
Plant width & -1.536 & 2.442 & $(1.058)$ & -.448 & -4.078 & 3.177 & -2.346 & 2.188 & .459 \\
Twenty pods length & -1.114 & .437 & -.085 & $(5.548)$ & -.7801 & -3.068 & .553 & -.945 & .546 \\
Shelling Percentage & -.106 & -.816 & -.932 & -.935 & $(4.630)$ & -.795 & -.676 & -.278 & .093 \\
100-kernel weight & -.563 & -.199 & -.810 & 4.554 & .985 & $(3.738)$ & .792 & -.48 & .450 \\
Leaflet length & .782 & -1.457 & -.842 & 1.040 & -1.061 & -1.003 & $(2.950)$ & -.552 & -.142 \\
Leaflet width & .611 & -.259 & -1.041 & 2.356 & .578 & -.807 & .732 & $(-2.225)$ & -.055 \\
\hline
\end{tabular}

Table 5: Yield performance of the studies advance lines of groundnut.

\begin{tabular}{|c|c|c|c|c|c|c|c|c|c|c|c|}
\hline $\begin{array}{l}\text { S. } \\
\text { No. }\end{array}$ & Line & $\begin{array}{l}\text { Number of } \\
\text { branches }\end{array}$ & $\begin{array}{l}\text { Plant } \\
\text { height }\end{array}$ & $\begin{array}{l}\text { Plant } \\
\text { width }\end{array}$ & $\begin{array}{l}\text { Twenty pods } \\
\text { length }\end{array}$ & $\begin{array}{l}\text { Shelling } \\
\text { Percentage }\end{array}$ & $\begin{array}{l}\text { 100-kernel } \\
\text { weight }\end{array}$ & $\begin{array}{l}\text { Leaflet } \\
\text { length }\end{array}$ & $\begin{array}{l}\text { Leaflet } \\
\text { width }\end{array}$ & $\begin{array}{l}\text { Dry pods } \\
\text { yield }\end{array}$ & $\begin{array}{l}\text { Yield } \\
\text { (Kg/ha) }\end{array}$ \\
\hline 1 & BARD-479 & 11 & 73.330 & 121 & 66.670 & 62.170 & 68.330 & 5.330 & 1.630 & 1853.330 & 2551 \\
\hline 2 & PG-1221 & 8.330 & 68.330 & 111 & 85 & 65.170 & 88.670 & 5.500 & 2.670 & 1964.670 & 3637 \\
\hline 3 & PG-1254 & 8.330 & 78.330 & 111.330 & 67 & 64.500 & 69.330 & 4.670 & 1.300 & 1775 & 3286 \\
\hline 4 & PG-1255 & 12.670 & 62 & 102.330 & 67.330 & 63.830 & 70.330 & 5.930 & 2.170 & 1508.330 & 2791 \\
\hline 5 & PG-1256 & 10.670 & 65.670 & 128.670 & 65.330 & 63.670 & 63 & 5.300 & 1.630 & 1531.670 & 2836 \\
\hline 6 & PG-1258 & 10.670 & 47.670 & 88.670 & 63 & 69.670 & 70.330 & 6.170 & 2.200 & 1576.670 & 2919 \\
\hline 7 & PG-1259 & 10.670 & 65.670 & 98.670 & 56.670 & 69.500 & 63 & 5.500 & 1.730 & 1378.330 & 3430 \\
\hline 8 & PG-1261 & 10 & 57.670 & 116 & 59.330 & 71.830 & 57 & 4.330 & 2.200 & 1567.330 & 1901 \\
\hline 9 & PG-1262 & 8.670 & 57.670 & 114.330 & 68.330 & 57.830 & 66 & 5.730 & 1.900 & 1295.330 & 2397 \\
\hline 10 & PG-1265 & 10.330 & 82.330 & 105.670 & 66.330 & 65.670 & 59.330 & 5.070 & 2.370 & 1299 & 2404 \\
\hline 11 & PG-1266 & 8 & 63 & 103.670 & 75.330 & 72.170 & 94.670 & 5.500 & 1.630 & 1716.330 & 3176 \\
\hline \multirow[t]{2}{*}{12} & PG-1267 & 11.670 & 68 & 83.330 & 74.670 & 67.330 & 95.670 & 5.230 & 2.300 & 1473.330 & 2727 \\
\hline & LSD & 3.700 & 10.290 & 17.230 & 2.920 & 4.450 & 4.860 & 1.470 & 0.520 & 505.800 & 353.240 \\
\hline
\end{tabular}

Journal of Innovative Sciences

June 2021 | Volume 7 | Issue 1 | Page 94 
To know about the direct and indirect effects of the characterized traits on dry pods yield, correlations were further divided into direct and indirect effects via path coefficient analysis (Table 4). Twenty pods length showed the highest positive direct effect (5.548) on dry pods yield, followed by S\% (4.630), 100-kernel weight (3.738), and Leaflet length (2.950). Our results are supported by Kushwah et al. (2016), who also found positive direct effect of 100-kernel weight on pod yield plant $^{-1}$. A weak positive direct effect was found on dry pods yield by number of branches (1.419), plant width (1.058), and plant height (0.311). The trait of leaflet width was observed with the direct negative effect on dry pods yield (-2.225). The direct and indirect positive and negative effects of the studied traits signify the importance of these traits for groundnut yield improvement. The importance of these traits in groundnut cultivar improvement also supported by earlier studies (Kumar et al., 2014; Rao et al., 2014; Shoba et al., 2012).

The evaluated advanced lines were further tested for yield performance. Based on the $\mathrm{kg} / \mathrm{ha}$ yield performance lines PG-1221, PG-1254, PG-1259, and PG-1266 were promising with $3637 \mathrm{~kg} / \mathrm{ha}, 3286 \mathrm{~kg} /$ ha, $3430 \mathrm{~kg} / \mathrm{ha}$, and $3176 \mathrm{~kg} / \mathrm{ha}$, respectively (Table 5). Further evaluation of these lines needed to develop high yielding cultivars in future breeding programs.

\section{Conclusions and Recommendation}

The highly significant association among the studied traits and direct and indirect effect of most traits on dry pods yield suggests that these traits must be considered in yield improvement of groundnut cultivar in future breeding programs. Furthermore, the current study showed that groundnut lines, PG1221, PG-1254, PG-1259, and PG-1266 are high yielding and having great potential for high yielding cultivar development.

\section{Acknowledgments}

The authors acknowledge the contribution of the Land Resources Research Institute, NARC, Islamabad for providing technical support in terms of experimental design.

\section{Novelty Statement}

Highly significant association was found among the studied traits in this study with direct and indirect effect of most traits on dry pods yield.

\section{Author's Contribution}

$\mathrm{NN}$ and MA designed and supervised the experiment, MJ and $\mathrm{MH}$ carried out the experiment, HK performed statistical analysis, SAK wrote and revised the manuscript.

\section{Conflict of interest}

The authors have declared no conflict of interest.

\section{References}

Al-Jibouri, H.A., Miller, P.A. and Robinson H.V., 1958. Genotypic and environmental variance and co-variance in an upland cotton cross of inter specific origin. Agronomy Journal, 50: 633636. https://doi.org/10.2134/agronj1958.0002 1962005000100020x

Aminifar, J., Nik, M.M. and Sirousmehr, A., 2013. Grain yield improvement of groundnut (Arachis bypogaea L) under drought stress conditions. International Journal of Agriculture and Crop Sciences, 6(12): 819-824.

Babariya, C.A. and Dobariya, K.L., 2012. Correlation coefficient and path coefficient analysis for yield components in groundnut (Arachis hypogaea L.). Electronic Journal of Plant Breeding, 3(3): 932-938.

Borkar, V.H. and Dharanguttikar, V.M., 2014. Evaluation of groundnut genotypes for physiological traits. International Journal of Environmental Research and Public, 4(1): 1-8.

Burton, G.W., 1952. Quantitative inheritance in grass. Proceedings of sixth international grassland congress, 1: 227-283.

Chavadhari, R.M., Kachhadia, V.H., Vachhani, J.H. and Virani, M.B., 2017. Genetic variability studies in groundnut (Arachis bypogaea L.). Electronic Journal of Plant Breeding, 8(4): 1288-1292. https://doi.org/10.5958/0975928X.2017.00184.3

Chu, Y., Chee, P., Isleib, T.G., Holbrook, C.C. and Ozias-Akins, P., 2020. Major seed size QTL on chromosome A05 of peanut (Arachis hypogaea) is conserved in the US mini core germplasm collection. Molecular Breeding, 40: 6. https:// doi.org/10.1007/s11032-019-1082-4

Coffelt, T.A. and Porter, D.M., 1982. 
Screeningpeanutsforresistance to sclerotinia blight. Plant Disease, 66: 385-387. https://doi. org/10.1094/PD-66-385

Cruz, C. and Regazzi, A., 1997. Modelos biométricos aplicados ao melhoramento genético, Viçosa, $M G$ : $U F V$.pp. 390.

Dewey, D.R., Agron, J. and Lu, K.H., 1959. Correlation and path analysis of component of created wheat grass seed production. 51: 513-518. https://doi.org/10.2134/agronj1959.00021962 005100090002x

Fernandez, M.G.S., Becraft, P.W., Yin, Y., and Lübberstedt, T., 2009. From dwarves to giants? Plant height manipulation for biomass yield. Trends in Plant Science, 14(8): 454-461. https:// doi.org/10.1016/j.tplants.2009.06.005

Gomes, C.N., Carvalho, S.P.d., Jesus, A.M.S. and Custódio, T.N., 2007. Caracterização morfoagronômica e coeficientes de trilha de caracteres componentes da produção em mandioca. Pesquisa agropecuária brasileira, pp. 1121-1130. https://doi.org/10.1590/S0100204X2007000800008

Gomes, R.L.F. and de Almeida Lopes, Â.C., 2005. Correlations and path analysis in peanut. Crop Breeding and Applied Biotechnology, 2005: 5. $\quad$ https://doi.org/10.12702/1984-7033. v05n01a14

Hampannavar, M.R., and Khan, H., 2019. Association study of morphological and physiological traits with yield in groundnut genotypes under terminal drought condition. International Journal of Current Microbiology and Applied Sciences, 8: 668-678. https://doi. org/10.20546/ijcmas.2019.801.075

Hugar, A. and Savithramma, D.L., 2015. Genetic variability studies for yield and surrogate traits related to water use efficiency in the recombinant inbred line (RIL) population derived from NRCG 12568 X NRCG 12326 of groundnut (Arachis hypogaea L.). International Journal of Agricultural Science Research, 5: 321-328.

Jaganathan, D., Bohra, A., Thudi, M., and Varshney, R.K., 2020. Fine mapping and gene cloning in the post-NGS era: advances and prospects. Theoretical and Applied Genetics, pp. 1-20. https://doi.org/10.1007/s00122-020-03560-w

Jibrin, M., Habu, S., Echekwu, C., Abdullahi, U. and Usman, I., 2016. Phenotypic and genotypic variance and heritability estimates for oil content and other agronomic traits in groundnut (Arachis hypogaea L.). Int. J. Sci. Res. Eng. Stud.,6: 3: 29-32.

Khan,A.,Bano,A.,Bakht,J.,Khan,S.A.,Malik, N.J. and Naz, I., 2009. Response of exotic groundnut genotypes to environmental diversities at higher altitude of northern Pakistan. Sarhad J Agric., 25(4): 545-550.

Kumar, C.P., Rekha, R., Venkateswarulu, O. and Vasanthi, R.P., 2014. Correlation and path coefficient analysis in groundnut (Arachis Hypogaea L.). International Journal of Applied Biology and Pharmaceutical Technology, 5 (1): 8-11.

Kushwah, A., Gupta, S., Sharma, S.R. and Pradhan, K., 2016. Genetic Variability, Correlation Coefficient and Path Coefficient Analysis for Yield and Component Traits in Groundnut. Indian Journal of Ecology, 43(2): 85-89.

Lampang A.N., Charoenwatana T. and Tiyawalee, D., 1980. In: ICRISAT (International Crops Research Institute for the Semi-Arid Tropics). Proceedings of the International workshop on groundnuts Patancheru, Andhra Pradesh,India.

Lv,J., Liu, N., Guo,J., Xu, Z., Li, X., Li, Z., Luo, H., Ren, X., Huang, Li., Zhou, X., Chen, Y., Chen, W., Lei, Y., Tu, J., Jiang, H. and Liao, B., 2018. Stable QTLs for plant height on chromosome A09 identified from two mapping populations in peanut (Arachis hypogaea L.). Front. Plant Sci., 9: 684. https://doi.org/10.3389/fpls.2018.00684

Nigam, S., 2014. Groundnut at a glance. The International Crops Research Institute for the Semi-Arid Tropics, pp. 121.

Oliveira, A.C., Vieira, E., Carvalho, F., Martins, L., Benin, G., Silva, J.A., Coimbra, J., Martins, A., Carvalho, M. and Ribeiro, G., 2007. Análise de trilha entre os componentes primários e secundários do rendimento de grãos em trigo. Current Agricultural Science and Technology, pp. 13.

Padmaja, D., Eswari, K., Rao, B.M. and Prasad, S.G., 2015. Genetic variability studies in F-2 population of Groundnut (Arachis bypogeaea L.). Helix, 1: 668-672.

Pandey, M.K., Monyo, E., Ozias-Akins, P., Liang, X., Guimarães, P., Nigam, S.N., Upadhyaya, H.D., Janila, P., Zhang, X. and Guo, B., 2012. Advances in Arachis genomics for peanut improvement. Biotechnology Advances, 30: 639-651. https://doi.org/10.1016/j. biotechadv.2011.11.001 
Pandey, M.K. and Varshney, R.K., 2018. Groundnut entered post-genome sequencing era: opportunities and challenges in translating genomic information from genome to field. In: Biotechnologies of Crop Improvement, 3: 199-209. https://doi.org/10.1007/978-3-319-947464_9

Pandey, M.K., Pandey, A.K., Kumar, R., Nwosu, C.V., Guo, B., Wright, G.C., Bhat, R.S., Chen, X., Bera, S.K. and Yuan, M., 2020. Translational genomics for achieving higher genetic gains in groundnut. Theoretical and Applied Genetics, pp. 1-24.

Rao, V., Venkanna, V., Bhadru, D. and Bharathi, D., 2014. Studies on variability, character association and path analysis on groundnut (Arachis bypogaea L.). International Journal of Pure and Applied Bioscience, 2: 194-197.

Raza, A., Khan, Z.H., Khan, K., Anjum, M.M., Ali, N., Iqbal, M.O. and Usman, H., 2017. Evaluation of Groundnut Varieties for the AgroEcological Zone of Malakand Division. Int. J. Environ. Sci. Nat. Res., 5(5): 555-671. https:// doi.org/10.19080/IJESNR.2017.05.555671

Santos, R., Custodio, R. and Santos, V., 2000. Eficiência reprodutiva em genótipos de amendoim e correlação fenotípica entre caracteres ligados ao ginóforo. Ciência $e$ Agrotecnologia, pp.24.

Shoba, D., Manivannan, N. and Vindhiyavarman, P., 2012. Correlation and path coefficient analysis in groundnut (Arachis bypogaea L.). Madras Agricultural Journal, 99: 18-20.

Shrey, A., Vasanthi, R., Ainmisha, K. and Srivastava, K., 2015. Correlation studies in early segregating generation in groundnut (Arachis bypogaea L.). Bioscan, 10: 1975-1979.

Singh, A.L., Davda, P.K. and Chaudhari, V., 2004. Role of pod and seed size in $\mathrm{P}$ and $\mathrm{Ca}$ nutrition of groundnut. In: Current trends of Research on Groundnut in India. Proceeding of national symposium on enhancing productivity of groundnut for sustaining food and nutritional security, NRCG, Junagadh 11-13 Oct. 04. National Research Centre for Groundnut (ICAR), Junagadh, India. 2004: 142-145.

Stalker,H.T.,2017.Utilizing wild species for peanut improvement. Crop Science, 57: 1102-1120. https://doi.org/10.2135/cropsci2016.09.0824

Yol, E., Furat, S., Upadhyaya, H.D. and Uzun, B., 2018. Characterization of groundnut (Arachis bypogaea L.) collection using quantitative and qualitative traits in the Mediterranean Basin. Journal of Integrative Agriculture, 17(1): 63-75. https://doi.org/10.1016/S20953119(17)61675-7

Zhuang, W., Chen, H., Yang, M., Wang, J., Pandey, M.K., Zhang, C., Chang, W.C., Zhang, L., Zhang, X., Tang, R., Garg, V., Wang, X., Tang, H., Chow, C.N., Wang, J., Deng, Y., Wang, D., Khan, A.W., Yang, Q., Cai, T., Bajaj, P., Wu, K., Guo, B., Zhang, X., Li, J., Liang, F., $\mathrm{Hu}$ J., Liao, B., Liu, S., Chitikineni, A., Yan, H., Zheng, Y., Shan, S., Liu, Q. Xie, D., Wang, Z., Khan, S.A., Ali, N., Zhao, C., Li, X., Luo, Z., Zhang, S., Zhuang, R., Peng, Z., Wang, S., Mamadou, G., Zhuang, Y., Zhao, Z., Yu, W., Xiong, F., Quan, W., Yuan, M., Li, Y., Zou, H., Xia, H., Zha, L., Fan, J., Yu, J., Xie, W., Yuan, J., Chen, K., Zhao, S., Chu, W., Chen, Y., Sun, P., Meng, F., Zhuo, T., Zhao, Y., Li, C., He, G., Zhao, Y., Wang, C., Kavikishor, P.B., Pan, R.L., Paterson, A.H., Wang, X., Ming, R. and Varshney, R.K., 2019. The genome of cultivated peanut provides insight into legume karyotypes, polyploid evolution and crop domestication. Nature Genetics, 51(5): 865-876. https://doi. org/10.1038/s41588-019-0402-2 